Article

\title{
Protective Effects of Ginger Extract against Glycation and Oxidative Stress-Induced Health Complications: An In Vitro Study
}

\author{
Shehwaz Anwar ${ }^{1}$, Ahmad Almatroudi ${ }^{1}{ }^{\circledR}$, Khaled S. Allemailem ${ }^{1}{ }^{\circledR}$, Rejo Jacob Joseph ${ }^{2}$, \\ Amjad Ali Khan ${ }^{2}$ and Arshad Husain Rahmani ${ }^{1, *}$ \\ 1 Department of Medical Laboratories, College of Applied Medical Sciences, Qassim University, P.O. Box 6699, \\ Buraidah 51452, Saudi Arabia; shehwazanwar25@gmail.com (S.A.); aamtrody@qu.edu.sa (A.A.); \\ k.allemailem@qu.edu.sa (K.S.A.) \\ 2 Department of Basic Health Science, College of Applied Medical Sciences, Qassim University, P.O. Box 6699, \\ Buraidah 51452, Saudi Arabia; r.joseph@qu.edu.sa (R.J.J.); akhan@qu.edu.sa (A.A.K.) \\ * Correspondence: ah.rahmani@qu.edu.sa
}

Received: 12 March 2020; Accepted: 14 April 2020; Published: 16 April 2020

check for updates

\begin{abstract}
Protein glycation and oxidative stress lead to severe health complications in various diseases including diabetes mellitus. The intake of flavonoid-rich foods has been confirmed previously to have a positive effect on human health. Ginger is an important source of flavonoids and is one of the most widely used traditional medicines in many Asian countries. The aim of this study was to verify the therapeutic potential of methanolic extract from ginger against glycation and other oxidative stress-induced complications using in vitro study. In this study, quantitative estimations of antioxidant components such as total phenolic and flavonoids were determined by UV-visible spectrophotometry. The anti-inflammatory action of the ginger extract was checked by determining its protective action against the denaturation of proteins, anti-proteinase activity and its membrane stabilization effect. The anti-inflammatory action of ginger extract was found to be comparable with reference standard drugs. The antiglycating effect of ginger extract was investigated by placing bovine serum albumin (BSA) with glucose in the presence and absence of ginger extract for two weeks at $37^{\circ} \mathrm{C}$. The incubated samples were analyzed for the number of glycation products, secondary structural changes, aggregation and advanced glycation end products (AGEs) formation by checking browning intensity, determination of aggregation index and Congo red assays. Our findings demonstrated that ginger extract $(600 \mu \mathrm{g} / \mathrm{mL})$ significantly reduced the browning, secondary structural changes, aggregation and AGEs formation. Thus, it can be concluded from these results that ginger extract is a wealthy source of antioxidants and can be used to prevent the glycation and oxidative stress-induced damage of biomolecules in various health complications including inflammation.
\end{abstract}

Keywords: ginger; glycation; oxidative stress; AGEs; inflammation; anti-glycating activity

\section{Introduction}

Diabetes mellitus has become a major health problem worldwide and is marked by elevated levels of blood glucose [1]. Long-term hyperglycemia is reported to be a key factor for diabetic complications [2] and glycation of biomolecules [3]. Protein glycation consists of a non-enzymatic series of reactions and leads to irreversible formation of several advanced glycation end products (AGEs) [3-7]. Glycation has been found to be a significant causative factor for several health-related issues [2,8]. Besides, the accumulation of AGEs (ultimate products of glycation) in vivo stimulates the pathogenesis of diabetes [9] via interaction of AGEs with their receptors (RAGEs) and, thus, by inducing the transcription of genes that control inflammation [10]. Hyperglycemia induced AGEs formation 
and glycation are associated with the development of foot ulcers [11], and the development of foot ulcers in diabetic patients, can progress in amputation due to peripheral vascular disease [12].

The formation of AGEs is accompanied by the generation of various free radicals and reactive oxygen species (ROS) and weakening of the antioxidant defense system of the body [13]. ROS are highly reactive oxygen-containing chemical species [14] that are generated continuously in the body due to the metabolism of cells [15]. The enhanced production and insufficient sequestration of ROS result in oxidative stress. Oxidative stress causes oxidative damaging of protein, nucleic acids and lipids, lipoproteins, carbohydrates and connective tissue macromolecules [16,17]. Oxidative stress and ROS have been implicated in the pathophysiology of several serious diseases such as aging, inflammation, cancer, diabetes, cardiovascular disease, arthritis, cataract, muscular degeneration, impaired wound healing, etc. [18]. However, oxidative stress and increased levels of glucose may cause irreversible damage of erythrocytes and ultimately induce hemolysis [16] and may initiate lipid peroxidation and destruction of the membrane, leading to tissue damage and inflammatory response. Besides, the activation of matrix metalloproteins by ROS results in severe damage of tissues like collagen, as seen in various arthritic reactions of the body [18]. Inflammatory processes are also considered to be linked with diabetes mellitus and its disorders [19].

Several pieces of scientific evidence have reported a strong correlation between antioxidant activity, total phenolic content and inhibition of AGEs formation [20,21]. Further, the consumption of a diet with rich antioxidants can be beneficial in the suppression of protein modifications. Thus, the intake of such foods can be a probable strategy against glycoxidative stress related to diabetic complications [22]. Fruits and vegetables are an important part of our daily diets that contain many polyphenolic compounds with valuable biological and pharmacological activities [23].

Ginger or Zingiber officinale Roscoe is an herbaceous rhizomatous plant and is an important member of the Zingiberaceae family. The rhizome of ginger has been used as an important dietary component and spice across the world [24]. In traditional folk medicines, ginger has been used for its wide array of medicinal properties such as anti-inflammatory, immunomodulatory, anti-tumorigenic, anti-apoptotic, anti-hyperglycemic, anti-lipidemic and anti-emetic, antimicrobial, hypoglycemic, antioxidant, hepatoprotective activities, etc. [25-27]. Targets of our study are to evaluate the antioxidant properties, and to explore its therapeutic potential in glycation and oxidative stress-induced health complications using various in vitro experiments. This study will be an important step towards understanding the correlation between its antioxidant capacity and its mechanism of preventing human diseases.

\section{Results}

\subsection{Preliminary Screening, Flavonoid and Phenolic Content}

The color, odor, texture and the percentage yield of methanolic extract of ginger are shown in Table 1.

Further, total phenolic compounds in the methanolic ginger extract were found to be $57.54 \pm 0.028 \mathrm{mg}$ gallic acid equivalent/g dry weight of extract that is close to those reported by earlier studies. It is noteworthy to say that phenolic contents indicate the product of defense against pathogens or stress in the environment and are not related to the growth functions and development of plant tissues [28].The total flavonoid content of the extract was measured with the aluminum chloride colorimetric assay using quercetin as standard. The content of total flavonoid in the ginger extract was $33.58 \pm 0.01 \mathrm{mg}$ quercetin equivalents/g dried weight of the extract. 
Table 1. Preliminary screening of ginger methanolic extract.

\begin{tabular}{cc}
\hline Preliminary Screening & Results \\
\hline Weight of dry powder of rhizome & $25 \mathrm{~g}$ \\
\hline Yield & $4.92 \%$ \\
\hline Extract & Methanol \\
\hline Color & Reddish brown \\
\hline Odor & Pungent \\
\hline Texture & Soft, oily \\
\hline Flavonoid (alkaline reagent test) & + \\
\hline Phenolic compounds $\left(\mathrm{FeCl}_{3}\right.$ test) & + \\
\hline
\end{tabular}

\subsection{In Vitro Antioxidant Assay: Ferric Reducing Antioxidant Power Assay}

In vitro, the antioxidant activity of ginger methanolic extracts was estimated by the ferric reducing antioxidant power method (FRAP) using ascorbic acid as standard. This is a simple, rapid and reproducible method that provides an estimate of total antioxidant concentration and is based on the ability of the extract to reduce $\mathrm{Fe}^{+3}$ to $\mathrm{Fe}^{+2}$. The ascorbic acid solution $(50-250 \mu \mathrm{g} / \mathrm{mL})$ conformed to Beer's Law at $700 \mathrm{~nm}$ with a regression coefficient $\left(R^{2}\right)=0.9966$. The plot has a slope $(\mathrm{m})=0.0038$ and intercept $=0.0219$. The equation of the standard curve is $y=0.0038 x+0.0219$. The FRAP value of the ginger methanolic extract was found to be $86 \pm 0.041 \mu \mathrm{g}$ ascorbic acid/mg dry weight of extract. Further, the reducing power ability of ginger extract was found to be comparable to standard (ascorbic acid). Figure 1 shows that the reducing power of ginger extract in terms of absorbance was proportionally increasing with an increase in concentration utilized. Values are presented as mean $\pm \operatorname{SEM}(n=3)$.

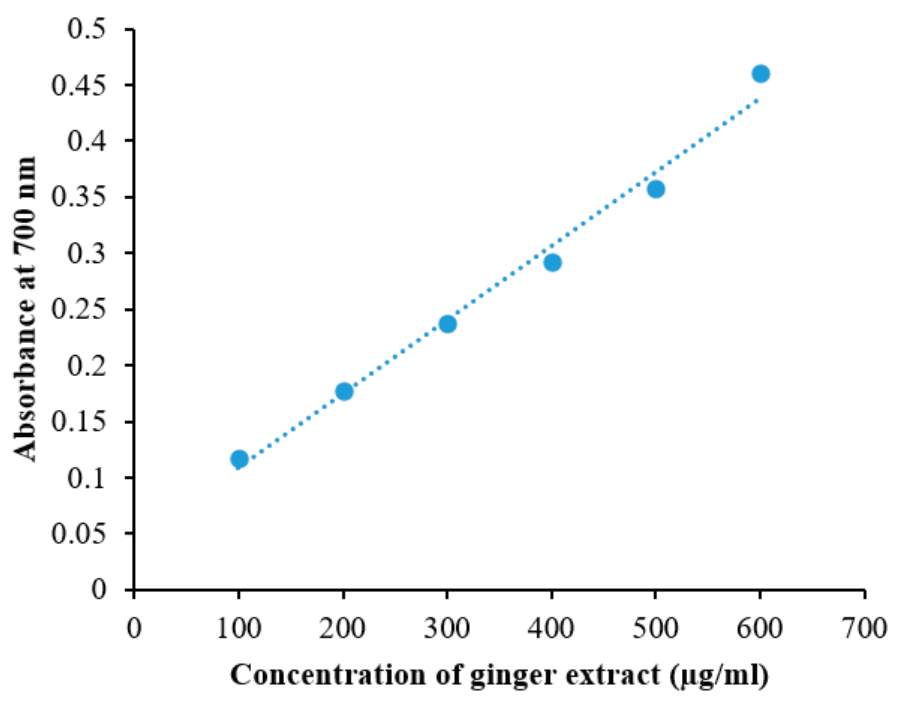

Figure 1. Reducing power of ginger extract in terms of absorbance at $700 \mathrm{~nm}$. The $X$-axis indicates the various concentrations of the ginger methanolic extract. The $Y$-axis shows the corresponding absorbance at $700 \mathrm{~nm}$. 


\subsection{Hydrogen Peroxide $\left(\mathrm{H}_{2} \mathrm{O}_{2}\right)$ Radical Scavenging}

Due to its antioxidant nature, the ginger methanolic extract has the potential to reduce ROS such as $\mathrm{H}_{2} \mathrm{O}_{2}$. The percentage ability of the methanolic ginger extract to scavenge $\mathrm{H}_{2} \mathrm{O}_{2}$ is shown in Figure 2 . The percentage of $\mathrm{H}_{2} \mathrm{O}_{2}$ scavenging activity against different concentrations of ginger methanolic extract as well as ascorbic acid are shown. The $\mathrm{H}_{2} \mathrm{O}_{2}$ scavenging activity of ginger extract increases in a concentration-dependent manner. The maximum percentage of scavenging activity is shown by $600 \mu \mathrm{g} / \mathrm{mL}$ of the ginger methanolic extract. The ascorbic acid showed good antioxidant activity in $100 \mu \mathrm{g} / \mathrm{mL}$. This antioxidant activity proves its correlation with a high content of polyphenolic compounds in the extract. Figure 2 shows the percentage of $\mathrm{H}_{2} \mathrm{O}_{2}$ scavenging activity of ginger methanolic extract.

\section{$\mathrm{H}_{2} \mathrm{O}_{2}$ scavenging activity}

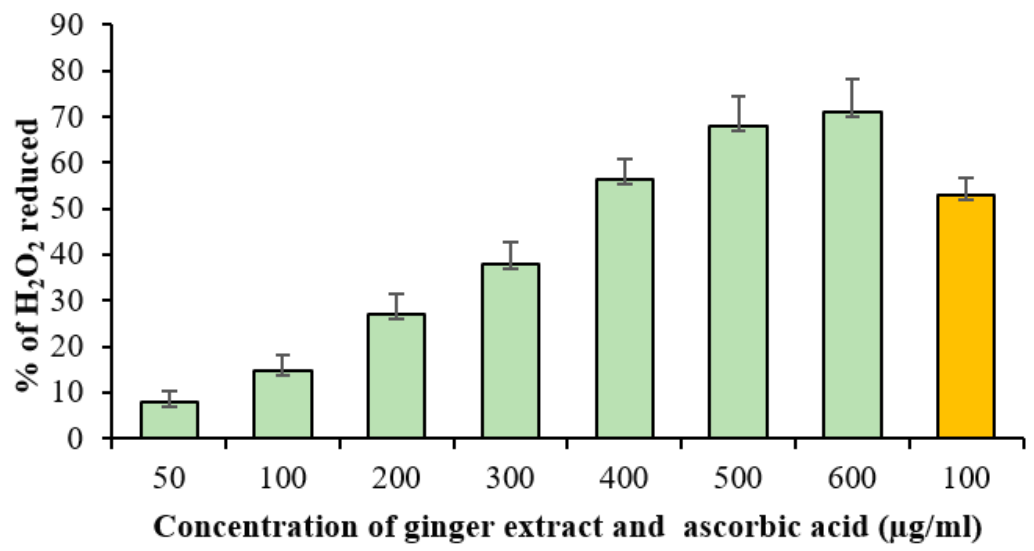

Figure 2. $\mathrm{H}_{2} \mathrm{O}_{2}$ scavenging activity of methanolic ginger extract. Samples 1 to 7 correspond to various concentrations of ginger extract $(50-600 \mu \mathrm{g} / \mathrm{mL})$. Sample 8 contained $100 \mu \mathrm{g} / \mathrm{mL}$ of standard antioxidant "ascorbic acid". The results are presented as means \pm SEM $(\mathrm{n}=3, p<0.05)$.

\subsection{DPPH Radical Scavenging Assay}

DPPH is a stable free radical that is widely used to evaluate the free radical scavenging potentials of various antioxidant substances. In the DPPH assay, DPPH accepts an electron or hydrogen radical from an antioxidant and becomes reduced to form yellow-colored diphenyl-picryl hydrazine. The reduction of DPPH by antioxidants can be estimated by the decrease in absorbance at $517 \mathrm{~nm}$. Figure 3 illustrates a significant increase in the free radical scavenging of DPPH because of the antioxidant nature of the ginger methanol extract and it is comparable to ascorbic acid. The results of the DPPH radical scavenging test of methanolic extract of ginger in comparison with the standard (ascorbic acid) are shown in Figure 3. The $\mathrm{EC}_{50}$ value of methanolic extract was found to be $422.36 \pm 0.04 \mu \mathrm{g} / \mathrm{mL}$ by a plot between the percentage of free radical scavenging activity and concentration of methanolic ginger extract with a regression coefficient $\left(R^{2}\right)=0.9766$. The plot has a slope $(m)=0.1091$ and intercept $=3.92$. The equation of the ginger methanolic extract curve is $y=0.1091 x+3.92$. Figure 3 shows the comparison of \% free radical scavenging activity of ascorbic acid and ginger extract in a bar graph. 


\section{Free radical scavenging activity}

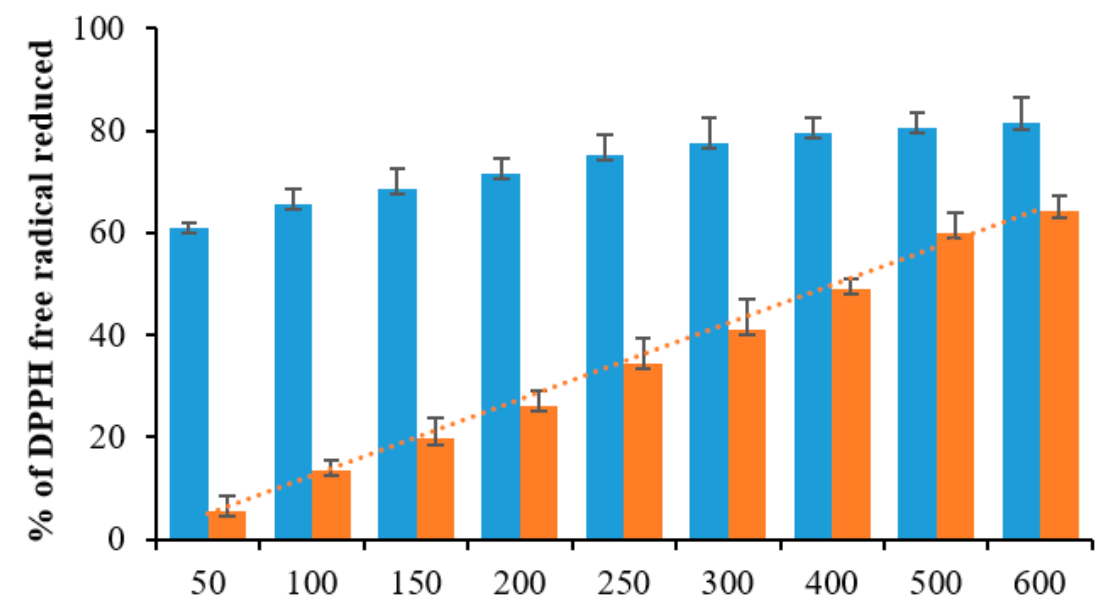

Concentration of ginger extract and ascorbic acid $(\mu \mathrm{g} / \mathrm{ml})$

Figure 3. Blue plot represents the curve having $\%$ of free radical reduced vs. concentration $(\mu \mathrm{g} / \mathrm{mL})$ of ascorbic acid while orange curve shows the $\%$ free radical scavenging activity vs. concentration $(\mu \mathrm{g} / \mathrm{mL})$ of methanolic ginger extract. The $p$-value significance was found to be less than 0.03 for this figure $(p<0.05)$.

\subsection{Protein Denaturation Inhibition}

During the denaturation process, quaternary, tertiary and secondary structures of protein become lost due to some external factors such as chemicals or stress. Inflammation is a protective complex process against injury and/or infection to initiate the healing process. Generally, some common incidents occur during inflammation including the increase of vascular permeability, increase of protein denaturation and membrane alteration. Protein denaturation has been documented to be one of the significant causes of inflammation and it involves alteration in electrostatic, hydrogen, hydrophobic and disulfide bonding. Besides, the denaturation of bovine serum albumin (BSA) leads to the expression of antigens that are associated with a type III hypersensitivity reaction and the initiation of an inflammatory response. Thus, to get some idea on the mechanism of the anti-inflammatory activity of ginger extract, its potential to protect from protein denaturation is investigated in this study. The ability of the ginger extract to inhibit heat-induced denaturation can be possibly a contributing factor for its anti-inflammatory activity.

The data suggest that the ginger methanolic extract is highly effective against heat-induced albumin denaturation and the percent inhibition of denaturation increases with an increase in the concentration of ginger extract. As a part of our study on the evaluation of the mechanism of the anti-inflammatory activity, the extract was found to be significantly effective in inhibiting the heat-induced albumin denaturation. Maximum inhibition of $39.66 \%$ was found at a concentration of $600 \mu \mathrm{g} / \mathrm{mL}$. Ibuprofen, a standard anti-inflammatory drug, showed the maximum inhibition, $61.01 \% \pm 0.36 \%$, at a concentration of $200 \mu \mathrm{g} / \mathrm{mL}$ (Figure 4). 


\section{Protection from heat-induced protein denaturation}

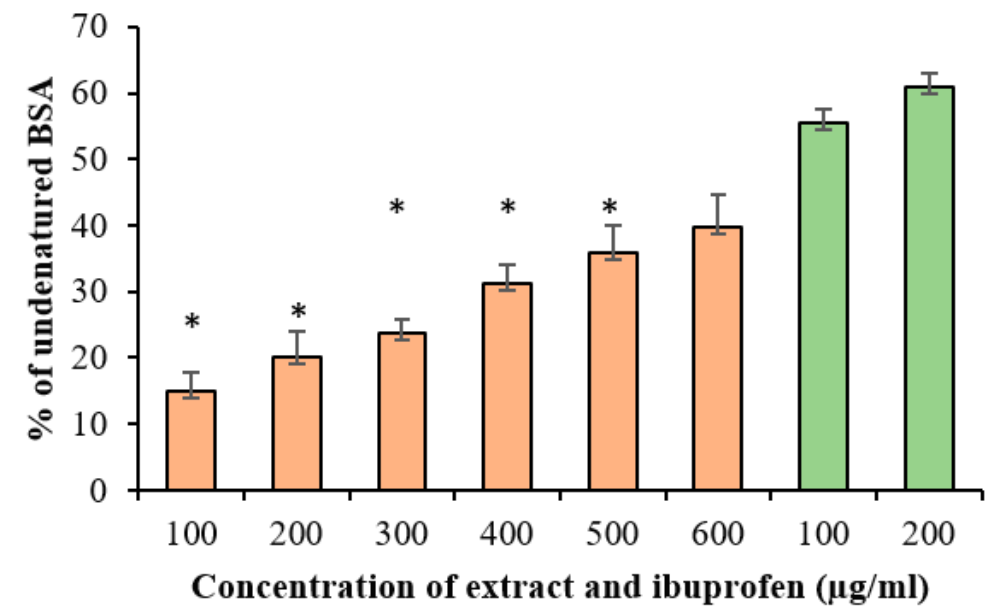

Figure 4. Protection from heat-induced protein denaturation. Samples from 1 to 6 at $X$-axis represent concentration 100-600 $\mathrm{\mu g} / \mathrm{mL}$ of ginger methanolic extract. Samples 7 and 8 denote a sample having reference drug ibuprofen with concentrations of 100 and $200 \mu \mathrm{g} / \mathrm{mL}$, respectively. The results are presented as means $\pm \operatorname{SEM}\left(\mathrm{n}=3,{ }^{*} p<0.05\right)$.

\subsection{Anti-Proteinase Activity}

Proteinases have been implicated in arthritic reactions. The ginger methanolic extract showed significant anti-proteinase activity and anti-proteinase activity of the ginger methanolic extract was found to increase in a concentration-dependent manner. Thus, the percent inhibition of denaturation increases with an increase in the concentration of ginger extract. The methanolic extract at $600 \mu \mathrm{g} / \mathrm{mL}$ showed maximum inhibition activity of $65.49 \%$. However, diclofenac sodium showed maximum inhibition of $73.39 \pm 0.056$ at $200 \mu \mathrm{g} / \mathrm{mL}$ (Figure 5).

\section{Anti-proteinase activity}

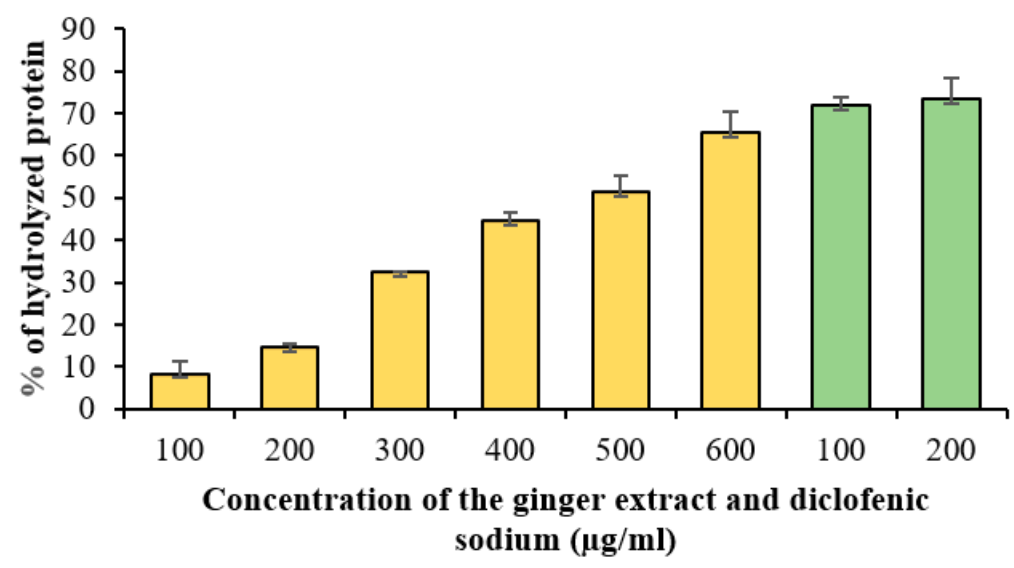

Figure 5. Anti-proteinase activity of the ginger extract. Samples 1-6 represent the various concentrations $(100-600 \mu \mathrm{g} / \mathrm{mL})$ of ginger methanolic extract. Samples 7 and 8, the last two samples, contained 100 and $200 \mu \mathrm{g} / \mathrm{mL}$ of diclofenac sodium, respectively. The results are presented as means $\pm \mathrm{SEM}(\mathrm{n}=3$, $p<0.05)$. 


\subsection{Membrane Stabilization Test}

Stabilization of the RBCs membrane was studied to further establish the mechanism of anti-inflammatory action of ginger.

\subsubsection{Heat-Induced Hemolysis}

The ginger methanolic extract was effective against heat-induced hemolysis and its ability to protect from heat-induced hemolysis of RBC increases with an increase in its concentration and shows the maximum inhibition $57.14 \% \pm 0.5 \%$ at $600 \mu \mathrm{g} / \mathrm{mL}$. The standard drug aspirin showed the maximum protection from hemolysis $74.63 \% \pm 0.007 \%$ at a concentration of $200 \mu \mathrm{g} / \mathrm{mL}$. Figure 6 shows the percentage of protection from heat-induced hemolysis of ginger methanol extract and aspirin.

\section{Protection from heat induced hemolysis}

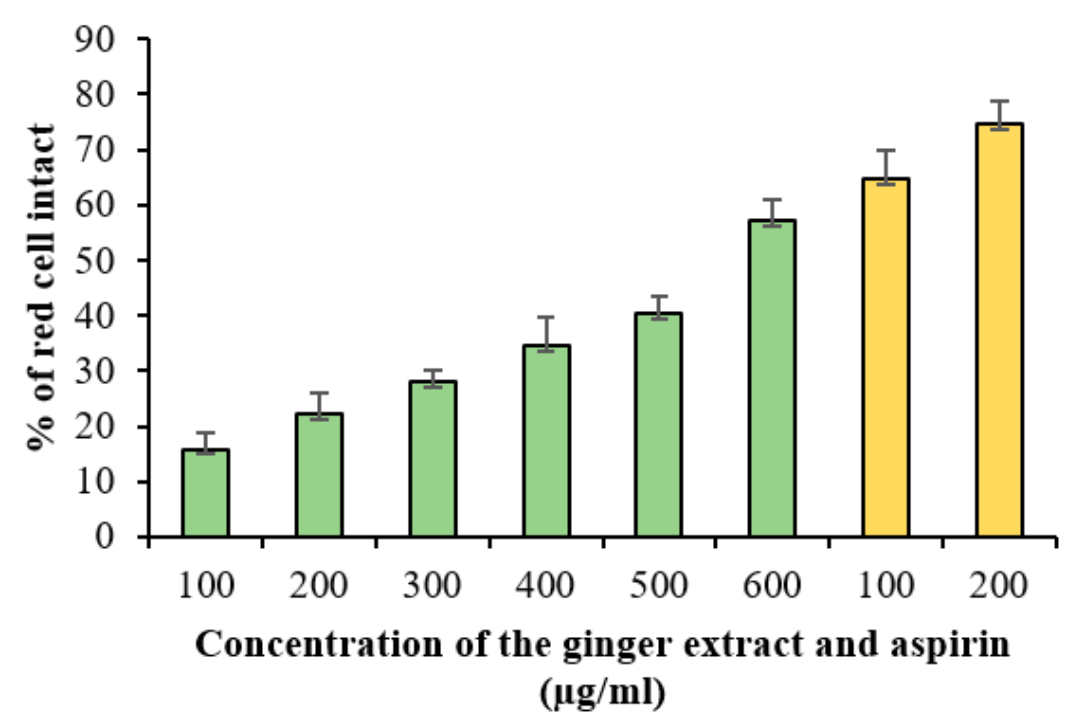

Figure 6. Protection from heat-induced hemolysis. Samples $1-6$ contained $100-600 \mu \mathrm{g} / \mathrm{mL}$ ginger methanolic extract, respectively. Samples 7 and 8 contained aspirin 100 and $200 \mu \mathrm{g} / \mathrm{mL}$, respectively. The results are presented as means $\pm \operatorname{SEM}(n=3, p<0.05)$.

\subsubsection{Hypotonicity-Induced Hemolysis}

The ginger extract showed significant protecting ability against hypotonicity-induced hemolysis. In hemolysis induced by hypotonicity, the osmotic loss occurs. The ginger methanol extract showed to inhibit hypotonicity-induced hemolysis and protect from osmotic loss in a concentration-dependent manner. The data suggest that this extract is capable of stabilizing the membrane of RBC and is a potent membrane stabilizer at high concentration $(600 \mu \mathrm{g} / \mathrm{mL})$ comparable to diclofenac sodium (Figure 7). 
Protection from hypotonicity-induced hemolysis

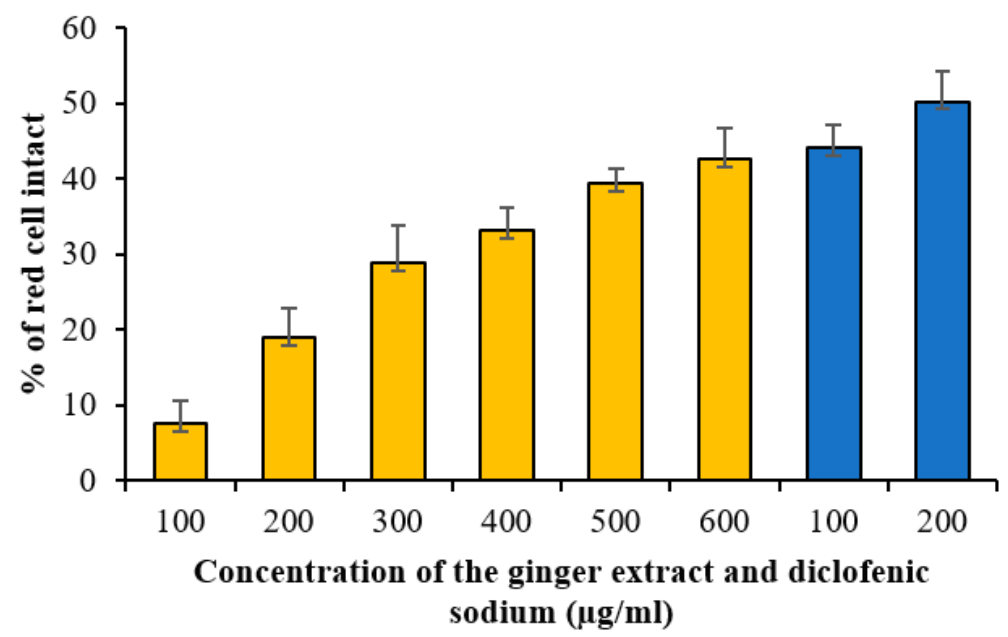

Figure 7. Protection from hypotonicity-induced hemolysis. The figure shows that the ginger methanolic extract provides protection against hypotonicity-induced hemolysis in a concentration-dependent manner. Samples 1-6 contained 100-600 $\mu \mathrm{g} / \mathrm{mL}$ of the ginger methanolic extract, respectively. Samples 7 and 8, the last two samples, contained 100 and $200 \mu \mathrm{g} / \mathrm{mL}$ diclofenac sodium as the reference drug. The results are presented as means $\pm \operatorname{SEM}(n=3, p<0.05)$.

\subsection{Effect of Ginger Extract on Proliferation of Aspergillus fumigatus}

Diabetic patients are more susceptible to fungal infections because of their immunosuppression. To see the influence of glucose and ginger extract on Aspergillus fumigatus, colony morphology and microscopy were studied (Figure 8).

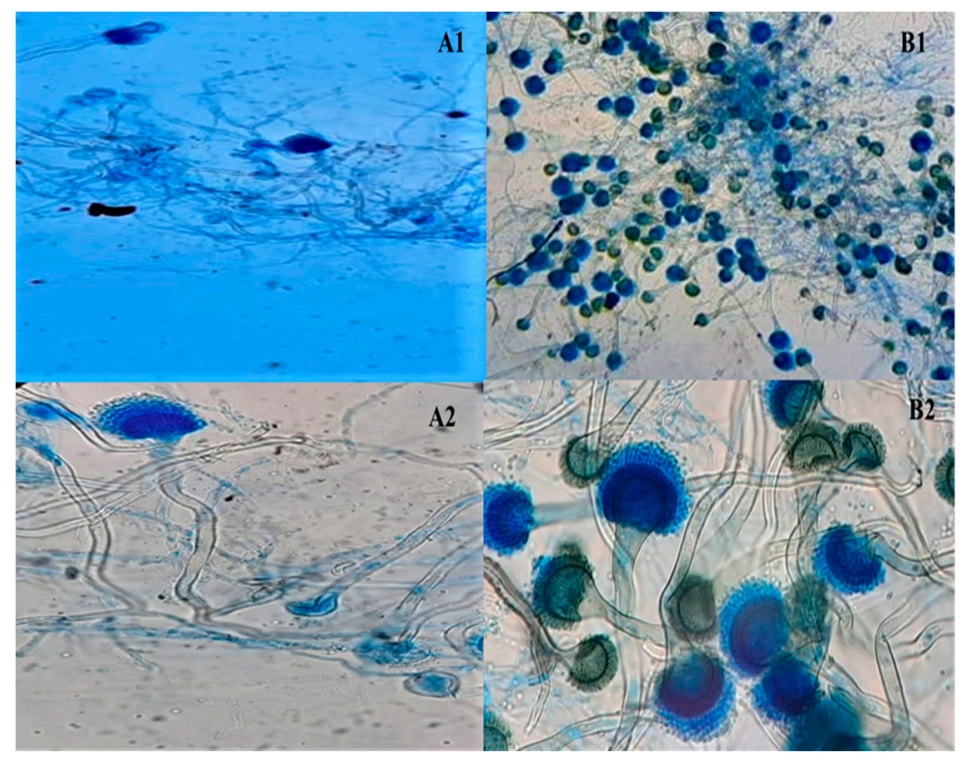

Figure 8. Microscopic study of A. fumigatus grown in media with high glucose content and in the presence or absence of ginger extract. A1 and A2 represent the $10 \times$ image and $40 \times$ image of $A$. fumigatus grown in media with high glucose content in the presence of ginger extract, respectively. B1 and B2 represent the $10 \times$ image and $40 \times$ image of $A$. fumigatus grown in media with high glucose content in absence of ginger extract, respectively. 
Our study showed significant variations in the morphology and microscopy of fungus growing on media with excessive concentration of glucose from the morphology and microscopy of fungus growing on media having a similar concentration of media but with ginger extract $(100 \mu \mathrm{g} / \mathrm{mL})$. A. fumigatus grown on control plates without any glucose or any other carbohydrate did not show any significant growth that demonstrates the necessity of sugar in the medium for fungal growth. A. fumigatus grown on media having glucose without ginger extract is soft, downy, granular and dark-green-colored. In addition, lactophenol cotton blue (LPCB) stain studies revealed that hyphae were septate with a smooth-walled conidiophore. Vesicles look pear-shaped and the phialides are closely compacted, uniseriate and formed above the upper two-thirds of the vesicle. Conidia are smooth to finely roughed, spherical and appear as chains above the phialides.

A. fumigatus grown on media having glucose with ginger extract is soft, downy, granular and of a gray-white color with no different border color in the morphological study. In addition, LPCB stain studies revealed that hyphae were septate with smooth-walled conidiophore. Vesicles look pear-shaped and the phialides are absent in most of the vesicles. Only a few vesicles were found to produce phialides and the conidia were also present above those phialides.

This data can be considered as an in vitro model for studying the growth of A. fumigatus under hyperglycemic conditions in diabetic patients that are kept with or without ginger extract. Thus, ginger extract may offer a therapeutic potential against the proliferation of fungus under hyperglycemic conditions.

\subsection{Effect of Ginger Extract on Browning}

BSA was incubated with glucose at $37^{\circ} \mathrm{C}$ for 15 days in the presence and absence of ginger methanolic extract. Browning intensity is the initial indicator for glycation [29] and the degree of browning was measured at $420 \mathrm{~nm}$. The data shows that ginger methanolic extract inhibited browning (hence, glycation) in a dose-dependent manner. The ginger methanolic extract exhibited $44.50 \% \pm 0.4 \%$ at $600 \mu \mathrm{g} / \mathrm{mL}$ browning as compared to glycated BSA incubated in the absence of ginger extract $(100 \%$, Figure 9$)$. These results indicate that the decrease in browning in the presence of ginger extract can be correlated with less formation of glycated brown products. The least browning was seen in BSA that was not incubated with the glucose that may possibly be due to time-dependent internal structural modifications. It is noteworthy that browning of BSA incubated with glucose in the absence of the ginger extract (control), was hypothetically considered to be $100 \%$ (maximum browning) and was not calculated placing its own absorbance (Ac) in the formula. The relative percent browning of other samples was calculated by placing As (absorbance of sample) and Ac (absorbance of control) in the formula. Thus, the degree of browning of different samples was decreased in a dose-dependent manner. The results indicated the protective effect of the ginger extract against glycation.

\subsection{Effect of Methanolic Ginger Extract on Protein Aggregation Index}

Aggregation of protein is one of the significant indicators of glycation because carbonyl groups bound to protein induce the formation of the cluster. BSA samples having ginger methanolic extract showed a very significant reduction in aggregation index as compared to glycated BSA in a concentration-dependent manner (Figure 10). 


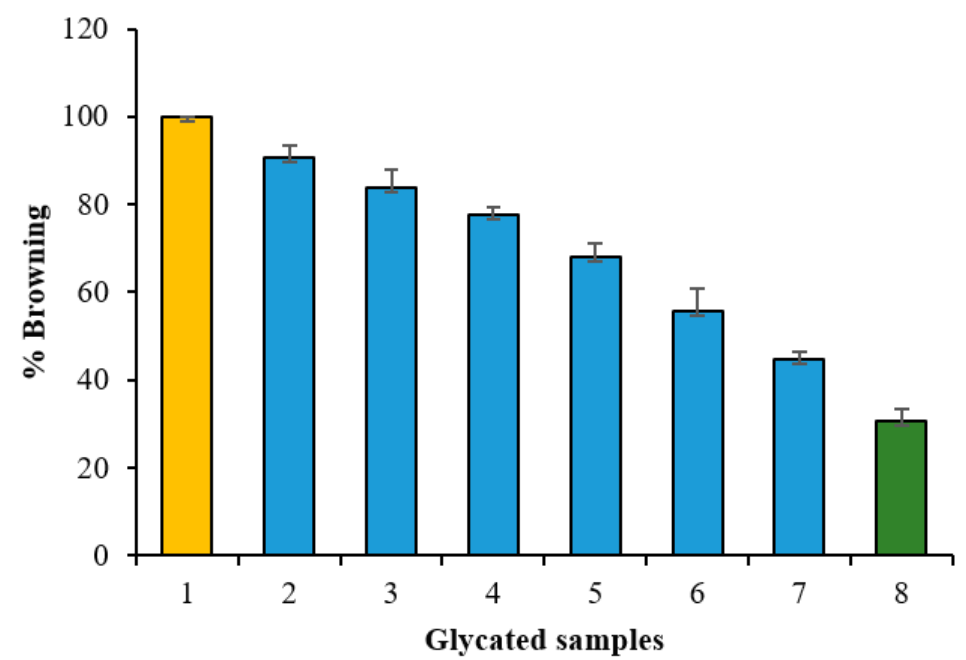

Figure 9. Decrease in browning in the presence of the ginger methanolic extract. Sample 1 corresponds to bovine serum albumin (BSA) incubated with glucose for 15 days and considered to show $100 \%$ glycation (browning). Samples 2-7 contained BSA and glucose with varying concentrations $(100-600 \mu \mathrm{g} / \mathrm{mL})$ of ginger methanolic extract. The browning intensity (the degree of glycation) is found to decrease with an increase in the concentration of the ginger methanolic extract. Sample 8 contained BSA incubated in the absence of glucose and ginger methanolic extract. It showed the least glycation. The results are presented as means $\pm \operatorname{SEM}(n=3, p<0.05)$.

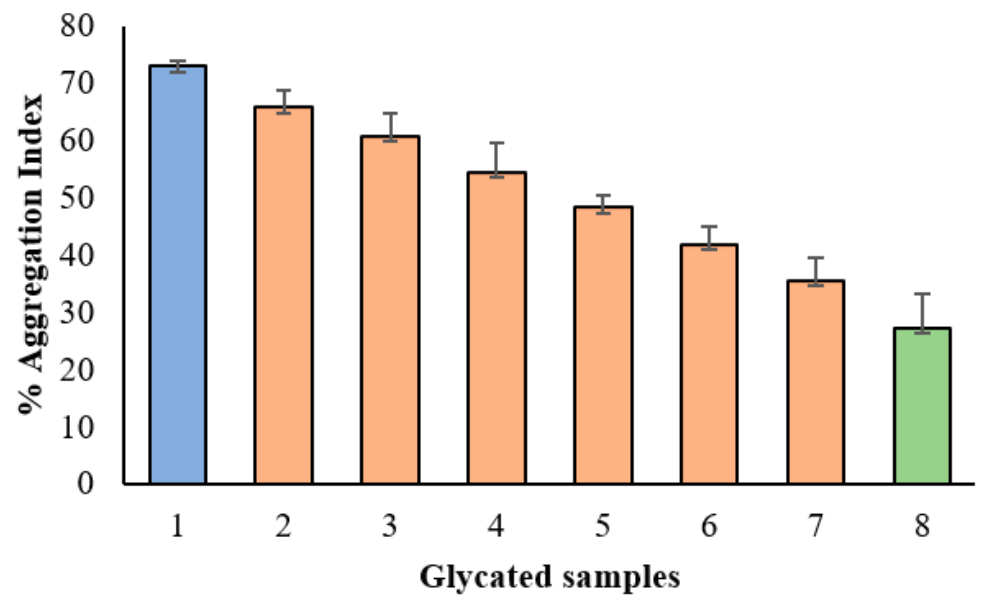

Figure 10. The decrease in aggregation index in the presence of ginger methanolic extract. Sample 1 corresponds to BSA incubated with glucose for 15 days and considered to show maximum aggregation index and, hence, glycation aggregation index. Samples 2-7 contained BSA and glucose with varying concentrations $(100-600 \mu \mathrm{g} / \mathrm{mL})$ of ginger methanolic extract and aggregation index is shown to decrease with an increase in the concentration of ginger methanolic extract. Sample 8 contained BSA incubated in the absence of glucose and ginger methanolic extract and showed the least aggregation index. The results are presented as means $\pm \operatorname{SEM}(n=3, p<0.05)$.

\subsection{Congo Red Assay}

To assess the protective effects of ginger extract on the development of the fibrillar state, amyloid-specific dye, Congo red (CR), was used in this study. CR has a specific binding capacity to the $\beta$-sheet structure of proteins and it binds perpendicularly to the amyloid-beta fibrils. The binding of $C R$ can be determined by recording absorbance at $530 \mathrm{~nm}$. The degree of modifications that occurred within secondary structures of protein, can be evaluated by Congo red binding assay. The dye 
binds to hydrophobic clefts between antiparallel $\beta$-strands. The results of the CR binding assay are presented in Figure 11. The ginger methanolic extract showed a reduction in fibrillation of BSA in a concentration-dependent manner.

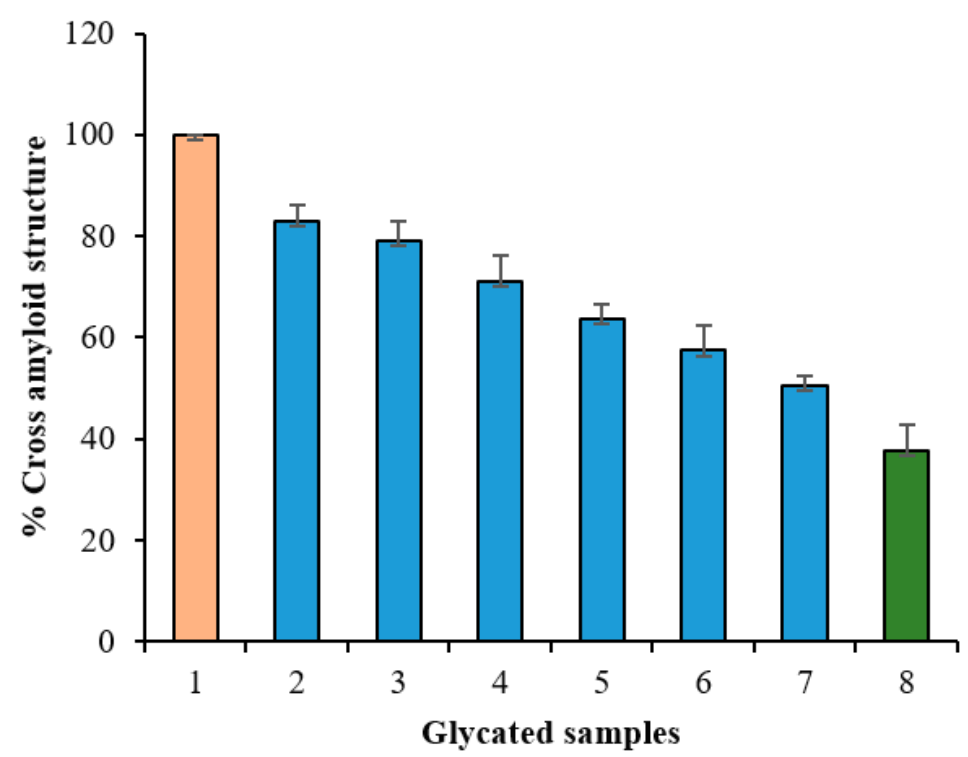

Figure 11. Decrease in cross amyloid structures in presence of ginger methanolic extract. Sample 1 corresponds to BSA incubated with glucose for 15 days and considered to show maximum structural maximum modifications and hence considered to be $100 \%$. Samples 2-7 contained BSA and glucose with varying concentration $(100-600 \mu \mathrm{g} / \mathrm{mL})$ of ginger methanolic extract and cross amyloid structures are shown to be decreased with increase in the concentration of ginger methanolic extract. Sample 8 contained BSA incubated in the absence of glucose and ginger methanolic extract and showed the least cross amyloid structures. The results are presented as means $\pm \operatorname{SEM}(n=3, p<0.05)$.

\section{Discussion}

Glycation, AGEs and oxidative stress have been concerned with several health issues. Intracellular ROS causes inhibition of glucose uptake and oxidative alteration of intracellular proteins [1] and their exposure to protein may cause fragmentation, aggregation, adverse interfering with ion channels, cell receptors and oxidative phosphorylation [30]. Glycation and the accumulation of AGEs lead to several diabetic complications such as the development of diabetic foot syndrome and aging increases the chance of major amputations due to foot ulcers. Thus, patients of diabetic foot syndrome highly suffer from severe neuro-psychiatric alterations [31] and their social and economic burden, morbidity and premature mortality due to this disease becomes increased [32].

Besides this, the formation of AGEs induces modification of physiological proteins to contribute significantly to the development of AGEs-related diseases [13]. The biggest challenge to develop potential strategies for the prevention of glycation and related complications is the detection of the formation of AGEs and glycation-induced processes. Many qualitative and quantitative methods have been developed for this purpose [33] such as browning, total AGEs estimation, CR assay for amyloid cross $\beta$-structure, aggregation index and electrophoretic mobility of biomolecules [13]. The potential to inhibit pro-inflammatory proteases is usually mentioned as to be related to the polyphenolic content of an extract and is an important strategy for the prevention of tissue injury which is also a diabetic complication [34].

These days, conventional therapies including natural products are more focused on the fight against diseases because of their beneficial effect in health promotion and reducing the risk of diseases. Previous studies on ginger rhizome have revealed its anti-proliferative, anti-inflammatory or anti-tumor activities, and it has been confirmed to be a potential source of various natural compounds that have 
been documented for the treatment of various diseases. High antioxidant activity is the characteristic feature of ginger extract and its efficiency to scavenge free radicals has been already discussed. In the present study, ginger extract was used to determine its therapeutic potential against glycation and glycation and oxidative stress-induced complications and methanolic extract of ginger were selected for this study. With the present study, we documented a positive correlation between the total phenolic content and DPPH assay, $\mathrm{H}_{2} \mathrm{O}_{2}$ scavenging activity and ferric reducing power assay and confirmed its strong antioxidant nature that was earlier reported to be correlated with the presence of phenolic compounds. Thus, our data suggest that high antioxidant activities and high phenolic content, especially flavonoids, present in ginger rhizome may be possible contributors to its medicinal properties. The formation of protein cross-links and aggregates due to glycation have been shown to be involved in neurodegenerative disorders [35]. The decrease in absorbance at $420 \mathrm{~nm}$ and the reduction of aggregation index in the presence of ginger extract showed a very significant reduction of amyloid cross $\beta$-structure as compared to glycated protein and it proved the therapeutic potential of ginger extract against glycation-induced structural alterations in proteins. The reduction of aggregation index by ginger extract confirms its anti-aggregation potential. Our observation from CR assay suggests the ability of ginger extract to protect the structural transition from $\alpha$-helix to cross $\beta$-structure. One possible explanation is that these extracts may have the ability to conceal the glycation sites extracts and to reduce the degree of the solvent-reachable surface area thus it does not allow the alterations in alpha conformers and suppress the formation of cross $\beta$-structure. The accumulation of AGEs is accompanied by the production of ROS in vitro and in vivo. The imbalance between production and removal of ROS exerts oxidative stress.

Many previous studies made ginger extract an interesting subject for its anti-inflammatory activity. Hence, our study further aimed to achieve a better understanding of its anti-inflammatory actions through an in vitro study. Denaturation of proteins may be an important factor for inflammation because it may cause the production of auto-antigens in certain inflammatory conditions. Stabilization of human red blood cell membrane and protection from heat-induced hemolysis can be possibly correlated with anti-inflammatory properties of a drug because the release of histamine from damaged tissues can also result in the destruction of nearby healthy tissues thus inducing inflammation [36]. Besides, anti-proteinase activity is also considered to be involved in controlling inflammatory disorders because of their ability to offer protection from proteinase induced tissue damage [37]. The results obtained from different anti-inflammatory tests including denaturation of BSA, heat and hyposalinity induced hemolysis, and anti-proteinase action in our study, have provided evidence that methanolic extract of ginger rhizomes have a probable anti-inflammatory activity that is comparable to standard anti-inflammatory drugs.

ROS and oxidative stress are well-documented factors for several diseases. Oxidative stress causes DNA mutations, damage and genome instability, as well as the initiation of pro-oncogenic signaling. These proceedings may ultimately result in carcinogenesis through various mechanisms. Further, chronic inflammation and cancer have been reported to be linked via the exacerbation of ROS, pro-inflammatory cytokines, as well as by providing an environment conducive for the exponential growth of malignant cells. Besides, structural modifications, aggregation and oxidative stress-induced by protein glycation and AGEs formation contribute significantly towards diabetes and its complications. Our in vitro results have indicated the significant antioxidant, anti-protein denaturation, membrane stabilization, anti-glycation and anti-aggregation activity of ginger extract. Thus, it can be presumed that intake of the ginger extract may offer therapeutic potential in delaying or preventing the onset of chronic diseases including cancer, diabetes and its complications such as diabetic foot syndrome, neurological diseases, etc. Our study further supports the findings of previous researchers that high content of flavonoids and other polyphenolic compounds may play a significant role in the antioxidant capacity of ginger extract and suggests that methanol can be used as the best solvent for extraction of plant materials. This extract can be applied in the formulation of several herbal drugs for the treatment of various health disorders such as diabetes, inflammation, arthritis and 
other oxidative stress-induced complications. In the future, animal studies will be performed at our laboratory in accordance with institutional guidelines using approved protocols to confirm various beneficial potentials (antioxidant, anti-inflammatory, antiglycating and AGEs formation inhibition activity) of the ginger methanolic extract in streptozotocin-induced male albino diabetic rats and mice.

\section{Materials and Methods}

\subsection{Materials}

Folin-Ciocalteu reagent, 2,2-diphenyl-1-picrylhydrazyl (DPPH), ferric chloride, potassium ferricyanide, gallic acid, trichloroacetic acid, ascorbic acid, quercetin, trypsin and Congo red were purchased from Sigma Co., St. Louis, Missouri, USA. DMSO, methanol, hydrochloric acid, aluminum chloride, monosodium dihydrogen phosphate, disodium hydrogen phosphate, sodium carbonate, sodium hydroxide and hydrogen peroxide were purchased from Merck, Darmstadt, Germany. All the chemicals and reagents were of analytical grade. The solvents used were of HPLC grade.

\subsection{Preparation of Crude Methanolic Ginger Extract}

The methanolic plant extract was prepared according to our standardized protocol. A hundred grams of dry plant powder was soaked in $1 \mathrm{~L}$ of $97 \%$ methanol for 3-5 days with intermittent shaking. At the end of extraction, it was passed through Whatman filter paper No.1 (Whatman Ltd., Maidstone, UK). This methanolic filtrate was concentrated under reduced pressure on a rotary evaporator at $40{ }^{\circ} \mathrm{C}$ and then stored at $4{ }^{\circ} \mathrm{C}$ for further use. The filtrate was reconstituted in the desired amount of $1 \%$ DMSO according to the need in sterile vials to obtain methanol extract of known concentration. The percentage of yield extracted was calculated as a \% yield by following equation:

$$
\% \text { yield }=[\text { Weight of sample extract/Initial weight of sample }] \times 100 .
$$

\subsection{Confirmatory Tests for Flavonoids and Phenolics}

The presence of flavonoids in the plant extract is checked by the alkaline reagent test. The intense yellow color comes by the addition of a few drops of sodium hydroxide into a test solution that disappears and the solution becomes colorless after the addition of a few drops of dilute $\mathrm{HCl}$. This will confirm the presence of flavonoids.

The presence of phenolic compounds can be confirmed by dissolving the sample in ethanol and the addition of a few drops of $1 \% \mathrm{FeCl}_{3}$. The formation of red, blue, green or purple coloration will confirm the presence of phenolic compounds.

\subsection{Total Phenol Content}

Total phenol content was determined using the Folin-Ciocalteu reagent. To $0.5 \mathrm{~mL}$ aliquot of dried methanolic extract, $2.5 \mathrm{~mL}$ of $10 \%$ Folin-Ciocalteu's reagent and $2 \mathrm{~mL}$ of $7.5 \%(w / v)$ sodium carbonate was added. The sample was incubated at room temperature for $30 \mathrm{~min}$ and the absorbance was checked at $760 \mathrm{~nm}$ by spectrophotometer (Shimadzu $1240 \mathrm{UV}$ mini spectrophotometer, Shimadzu, Kyoto, Japan). A standard calibration plot was generated using different concentrations of gallic acid $(50-250 \mu \mathrm{g} / \mathrm{mL})$. The concentration of total phenolic content in the methanolic extract was calculated using this standard. Total phenolic content was expressed as mg gallic acid equivalents (GAE). All tests were performed in triplicates and the results were expressed as $\mathrm{mg}$ gallic acid equivalents per gram sample extract.

Total phenolic content was calculated using the equation:

$$
\mathrm{TPC}=\mathrm{C} \times \mathrm{V} / \mathrm{M}
$$


where $\mathrm{C}$ is the concentration of gallic acid $(\mathrm{mg} / \mathrm{mL})$ and $\mathrm{V}$ is volume of plant extract in $\mathrm{mL}$ and $\mathrm{M}$ is the weight of pure plant extract in gram.

\subsection{Total Flavonoid Content}

The methods of Ordonez et al. [38] and Taie et al. [39] were followed for the measurement of total flavonoid content using aluminum chloride $\left(\mathrm{AlCl}_{3}\right)$ colorimetric assay. In brief, $0.5 \mathrm{~mL}$ of $2 \%$ $\mathrm{AlCl}_{3}$ in ethanol solution was added to $0.5 \mathrm{~mL}$ of the extract $(50 \mu \mathrm{g} / \mathrm{mL})$ or standard quercetin solution $(20-250 \mu \mathrm{g} / \mathrm{mL})$ in test tubes separately. The reaction mixture was incubated for $1 \mathrm{~h}$ at room temperature. The development of yellow color indicates the presence of flavonoids. The absorbance was measured at $420 \mathrm{~nm}$ against the sample blank. The total flavonoid content was calculated and expressed in terms of a milligram of quercetin equivalent per gram of crude extract (mg QUE/g) using a calibration curve prepared with quercetin.

Total flavonoid content was calculated using the equation:

$$
\mathrm{TFC}=\mathrm{C} \times \mathrm{V} / \mathrm{M}
$$

where $\mathrm{C}$ is the concentration of quercetin in $\mathrm{mg} / \mathrm{mL}, \mathrm{V}$ is volume of plant extract in $\mathrm{mL}$ and $\mathrm{M}$ is the weight of pure plant extract in gram.

\subsection{In Vitro Antioxidant Activity: Reducing Power}

In vitro, antioxidant assay was estimated by ferric reducing antioxidant power (FRAP) method [40]. To $2.5 \mathrm{~mL}$ of aliquots of various concentrations of ascorbic acid and 100 to $600 \mu \mathrm{g} / \mathrm{mL}$ of ginger extract, $2.5 \mathrm{~mL}$ of $0.2 \mathrm{M}$ phosphate buffer $(\mathrm{pH} 6.6)$ and $2.5 \mathrm{~mL}$ of $1 \%$ potassium ferricyanide $(w / v)$ were added. The reaction mixture was incubated at $50{ }^{\circ} \mathrm{C}$ for $30 \mathrm{~min}$ and was rapidly cooled by running water after completion of incubation. Later, a $2.5 \mathrm{~mL}$ of $10 \%$ trichloroacetic acid $(w / v)$ was added and the mixture was centrifuged at $3000 \mathrm{rpm}$ for $10 \mathrm{~min}$. Afterward, $2.5 \mathrm{~mL}$ of supernatant was collected and was mixed with $2.5 \mathrm{~mL}$ of distilled water. The resultant was vortexed for a short time and $0.5 \mathrm{~mL}$ of $0.1 \%$ ferric chloride $\left(\mathrm{FeCl}_{3}\right)$ solution (freshly prepared) was added until the green-colored solution is formed. The mixture was allowed to stand for $10 \mathrm{~min}$ and the absorbance of standard and test samples was measured at $700 \mathrm{~nm}$. Distilled water with no added extracts was used as a blank. Ascorbic acid was used as standard and all the samples were run in triplicate.

\subsection{Estimation of Free Radical Scavenging Activity by DPPH Method}

1,1 difenyl-2-picryl-hydrazyl (DPPH) was used to measure the antioxidant activity of methanolic ginger extract. In brief, the stock solution $(10 \mathrm{mg} / \mathrm{mL})$ of the ginger extract was diluted to a final concentration of $50 \mu \mathrm{g} / \mathrm{mL}$ in methanol. Later, $1 \mathrm{~mL}$ of $0.3 \mathrm{mM}$ DPPH in methanol was added to $2.5 \mathrm{~mL}$ of the sample solution of different concentrations and allowed to stand in dark for $30 \mathrm{~min}$ at room temperature. The absorbance of all the samples was measured at $517 \mathrm{~nm}$ against methanol as a blank and the inhibitory effect of DPPH was calculated according to the following equation:

$$
\% \text { of free radical scavenging activity }=[(\mathrm{Ac}-\mathrm{As}) / \mathrm{Ac}] \times 100
$$

where $\mathrm{Ac}=$ Absorbance of control and As $=$ Absorbance in presence of extract.

\subsection{Hydrogen Peroxide $\left(\mathrm{H}_{2} \mathrm{O}_{2}\right)$ Radical Scavenging Ability}

The $\mathrm{H}_{2} \mathrm{O}_{2}$ scavenging ability of ginger extract was determined according to the method of Ruch et al. [41]. A solution of $40 \mathrm{mM} \mathrm{H}_{2} \mathrm{O}_{2}$ was prepared in phosphate buffer saline (pH 7.4). To a series of various concentrations of methanolic ginger extract $(50-600 \mu \mathrm{g} / \mathrm{mL}), 1 \mathrm{~mL}$ of $\mathrm{H}_{2} \mathrm{O}_{2}$ solution $(40 \mathrm{mM})$ was added in dark. The absorbance of hydrogen peroxide at $230 \mathrm{~nm}$ was determined after $10 \mathrm{~min}$ using a UV-visible spectrophotometer against a blank solution. The blank contained the phosphate 
buffer without $\mathrm{H}_{2} \mathrm{O}_{2}$. The results were compared with the percentage scavenging ability of ascorbic acid as a standard $(100 \mu \mathrm{g} / \mathrm{mL})$. All the samples were run in triplicates. The percentage of scavenged $\mathrm{H}_{2} \mathrm{O}_{2}$ was calculated using the following equation:

$$
\% \text { of scavenged } \mathrm{H}_{2} \mathrm{O}_{2}=[(\mathrm{Ac}-\mathrm{As}) / \mathrm{Ac}] \times 100
$$

where $\mathrm{Ac}=$ Absorbance of control and As $=$ Absorbance in presence of extract.

\subsection{Protein Denaturation Inhibition: An Evaluation of In Vitro Anti-Inflammatory Activity}

The anti-inflammatory action of the ginger extract by albumin denaturation inhibition was studied according to the method of Sakat et al. [18] and Mizushima and Kobayashi [42] with slight modifications. Briefly, $1 \%$ aqueous solution of bovine serum albumin $(500 \mu \mathrm{L})$ was added separately to $100 \mu \mathrm{L}$ of various concentration $(100-600 \mu \mathrm{g} / \mathrm{mL})$ of ginger extract as well as 100 and $200 \mu \mathrm{g} / \mathrm{mL}$ of ibuprofen. The mixtures were incubated at $37^{\circ} \mathrm{C}$ for $20 \mathrm{~min}$ and then heated at $51{ }^{\circ} \mathrm{C}$ for $20 \mathrm{~min}$. The samples were cooled down and turbidity was measured at $660 \mathrm{~nm}$ using. The samples were run in triplicates.

The percentage inhibition of protein denaturation was calculated using the following equation:

$$
\text { Percentage Inhibition }=[(\mathrm{Ac}-\mathrm{As}) / \mathrm{Ac}] \times 100
$$

where $\mathrm{Ac}=$ Absorbance of control and As $=$ Absorbance in presence of extract/ibuprofen .

\subsection{Anti-Proteinase Action: Evaluation of In Vitro Anti-Inflammatory Activity}

The anti-proteinase action of ginger extract was determined by a modified method of Sakat et al. [18] and Oyedepo et al. [43]. For this, $0.06 \mathrm{mg}$ trypsin, $1 \mathrm{~mL} 20 \mathrm{mM}$ Tris $\mathrm{HCl}$ buffer (pH 7.4) and $1 \mathrm{~mL}$ ginger extract of varying concentrations $(100-600 \mu \mathrm{g} / \mathrm{mL})$ or diclofenac sodium $(100$ and $200 \mu \mathrm{g} / \mathrm{mL})$ in $2 \mathrm{~mL}$ reaction mixture were first incubated at $37^{\circ} \mathrm{C}$ for $5 \mathrm{~min}$. After incubation, $1 \mathrm{~mL}$ of $0.8 \%(w / v)$ casein was added. The mixture was kept for an additional $20 \mathrm{~min}$. After $20 \mathrm{~min}$, the reaction was arrested by the addition of $2 \mathrm{~mL}$ of $70 \%$ perchloric acid and the cloudy suspension was centrifuged for $5 \mathrm{~min}$ at $2500 \mathrm{rpm}$. The absorbance of the supernatant was recorded at $210 \mathrm{~nm}$ using the buffer as blank. All the tests were run in triplicates. The percentage inhibition of proteinase inhibitory activity was calculated by following equation:

$$
\text { Percentage inhibition }=[(\mathrm{Ac}-\mathrm{As}) / \mathrm{Ac}] \times 100
$$

where $A c=$ Absorbance of control and As $=$ Absorbance in presence of extract/diclofenac sodium.

\subsection{Membrane Stabilization}

\subsubsection{Red Blood Cell (RBC) Suspension Preparation}

Fresh human blood, collected from a healthy volunteer was transferred to the heparinized centrifuged tubes and mixed with Alsever's solution in equal proportion and the resulting mixture was centrifuged at $3000 \mathrm{rpm}$ for $10 \mathrm{~min}$. Supernatant plasma was discarded and the erythrocyte sediments were washed thrice with an equal volume of normal saline. The blood was reconstituted with isotonic phosphate buffer having $\mathrm{pH} 7.4$ and a 10\% $v / v$ human RBC suspension was prepared [44].

\subsubsection{Heat-Induced Hemolysis}

The reaction mixture $(2 \mathrm{~mL})$ contained $1 \mathrm{~mL}$ of ginger extract of varying concentrations $(100-600 \mu \mathrm{g} / \mathrm{mL})$ or aspirin $(100,200$ and $300 \mu \mathrm{g} / \mathrm{mL})$ and $1 \mathrm{~mL} \mathrm{10 \%} v / v$ human RBC suspension. All the tubes were incubated in a water bath at $56^{\circ} \mathrm{C}$ for $30 \mathrm{~min}$ and the tubes were cooled under running tap water. The reaction mixture was centrifuged at $2500 \mathrm{rpm}$ for $5 \mathrm{~min}$ at room temperature. The absorbance of the supernatant was recorded at $560 \mathrm{~nm}$. Phosphate buffer was taken as blank and 
control composed of only buffer and RBC suspension without drug/extract [18]. Percent protection from heat-induced hemolysis was calculated according to the following equation:

$$
\text { Percentage protection }=[(\mathrm{Ac}-\mathrm{As}) / \mathrm{Ac}] \times 100
$$

where $\mathrm{Ac}=$ Absorbance of control and As $=$ Absorbance in presence of extract/aspirin .

\subsubsection{Hypotonicity-Induced Hemolysis}

The protective action of ginger extract against hypotonicity-induced hemolysis was determined by a modified method of Chanda and Juvekar [44]. A $1 \mathrm{~mL}$ volume of various concentrations of ginger extract $(100-600 \mu \mathrm{g} / \mathrm{mL})$, reference sample and control were separately mixed with $1 \mathrm{~mL}$ of phosphate buffer (pH 7.4, $0.1 \mathrm{M}), 2 \mathrm{~mL}$ of hyposaline $(0.36 \%)$ and $0.5 \mathrm{~mL}$ of $10 \% v / v$ HRBC suspension. Diclofenac sodium (100 and $200 \mu \mathrm{g} / \mathrm{mL}$ ) was used as a reference standard drug and was dissolved in distilled water. A $2 \mathrm{~mL}$ volume of distilled water was added instead of hyposaline in control. All the assay mixtures were incubated at $37^{\circ} \mathrm{C}$ for $30 \mathrm{~min}$ and centrifuged at $3000 \mathrm{rpm}$ for $10 \mathrm{~min}$. The absorbance of the supernatant was estimated at $540 \mathrm{~nm}$. The percentage of hemolysis was calculated by assuming the hemolysis produced in the presence of distilled water (hypotonic solution) to be $100 \%$. Thus, the percent inhibition of hypotonicity-induced hemolysis was calculated using the following equation:

$\%$ inhibition of hypotonicity-induced hemolysis $=100-[(\mathrm{As} / \mathrm{Ac}) \times 100]$

where Ac $=$ Absorbance of control and As $=$ Absorbance in presence of extract/diclofenac sodium.

\subsection{Antifungal Activity of Ginger Extract against Aspergillus fumigatus}

Diabetic patients are more prone to fungal diseases because of immunosuppressive effects [45]. To see the effect of glucose on the proliferation of fungus and anti-proliferating activity of the ginger extract, the protocol used by Hamad and colleagues was followed with some modifications [46]. Aspergillus fumigatus was plated on potato dextrose agar (PDA) medium and was incubated at $30^{\circ} \mathrm{C}$ for 5 days. The fungus obtained from a pure culture of PDA was transferred to plates having modified Czapek Dox Agar $\left(\mathrm{NaNO}_{3}: 3 \mathrm{~g}, \mathrm{MgSO}_{4} \cdot \mathrm{H}_{2} \mathrm{O}: 0.5 \mathrm{~g}, \mathrm{KCl}: 0.5 \mathrm{~g}, \mathrm{KH}_{2} \mathrm{PO}_{4}: 1.0 \mathrm{~g}\right.$, agar: $20 \mathrm{~g}$ and a varying amount of glucose: 0 to $100 \mathrm{~g}$, water: $1000 \mathrm{~mL}$ ) to observe the effect of sugar in media on the growth of fungus (and, to correlate it with the growth of $A$. fumigatus in hyperglycemic conditions). The antiproliferative activity of the ginger extract against $A$. fumigatus was studied by adding $30 \mu \mathrm{L}$ of ginger extract in each plate having varying amounts of glucose mentioned above and the final concentration of ginger extract was $100 \mu \mathrm{g} / \mathrm{mL}$ in each test plate. The control used was simple dox media without sugar content or ginger extract [47].

\subsection{Antiglycating and AGEs Inhibiting Property of Ginger Extract}

\subsubsection{Incubation of Ginger Extracts with In Vitro Glycation System}

This experiment was adopted from the methodology of Brownlee with slight modifications. An aqueous solution of BSA $(10 \mathrm{mg} / \mathrm{mL})$ was incubated under the sterile condition with glucose $(500 \mathrm{mM})$ in $0.1 \mathrm{M}$ phosphate buffer ( $\mathrm{pH} \mathrm{7.4)}$ at $37^{\circ} \mathrm{C}$ for 15 days in the dark with a gentle shaking [48]. Some of the incubated samples contained varying amounts of ginger extract $(100-600 \mu \mathrm{g} / \mathrm{mL})$. Incubation was carried out in autoclaved closed capped glass vials. All the solutions used were filter-sterilized $(0.2 \mu \mathrm{m}$ membrane). After completion of incubation, the incubated media was dialyzed for removal of bound and unbound glucose at $37^{\circ} \mathrm{C}$ against $50 \mathrm{mM}$ phosphate buffer $\mathrm{pH} 7.4$ overnight. Following dialysis, the samples were stored at $-20^{\circ} \mathrm{C}$ prior to analysis. After dialysis, the protein concentration was determined using the molar extinction coefficient method. Bacterial contamination was prevented by the addition of $3 \mathrm{mM} / \mathrm{L}$ sodium azide. All experiments were run in triplicate. 


\subsubsection{Measurement of Browning in Glycated Samples}

The extent of browning in glycated samples was determined by recording the absorbance of each sample at $420 \mathrm{~nm}$ [13] and all the experiments were carried in triplicates. The relative percentage of protection from browning was calculated by the following equation:

$$
\text { Percentage protection }=[(\mathrm{Ac}-\mathrm{As}) / \mathrm{Ac}] \times 100
$$

where Ac $=$ Absorbance of BSA and glucose system and As $=$ Absorbance of BSA and glucose system incubated with ginger extract.

\subsubsection{Effect of Ginger Extract on Protein Aggregation Index}

The effect of ginger extracts was also checked on the protein aggregation by measuring the absorbance of glycated samples [13] in the presence and absence of ginger extract. The aggregation index was calculated by the following equation

$$
\text { Percentage of protein aggregation index }=\left[\mathrm{A}_{340} /\left(\mathrm{A}_{280}-\mathrm{A}_{340}\right)\right] \times 100
$$

where $\mathrm{A}_{340}=$ Absorbance at $340 \mathrm{~nm}$ and $\mathrm{A}_{280}=$ Absorbance at $280 \mathrm{~nm}$.

\subsubsection{Determination of Fibrillar State by Congo Red Assay}

The inhibition of glycation mediated fibrillation of BSA was determined, based on the binding of amyloid-specific dyes such as Congo red (CR) as mentioned by Klunk et al. [49]. CR binding assay was carried out by measuring the absorbance for AGE-BSA and BSA (control) separately, as well as for the Congo red background. Briefly, $500 \mu \mathrm{L}$ of glycated protein solution $(100 \mu \mathrm{M})$ was incubated with $100 \mu \mathrm{L}$ of $\mathrm{CR}(100 \mu \mathrm{M}$ Congo red in the phosphate buffer saline- $10 \%(v / v)$ ethanol). The absorbance was recorded at $530 \mathrm{~nm}$ and results were expressed as the percent inhibition of amyloid formation by following equation:

$$
\% \text { inhibition of amyloid formation }=[(\mathrm{Ac}-\mathrm{As}) / \mathrm{Ac}] \times 100
$$

where Ac $=$ Absorbance of BSA and glucose system and As $=$ Absorbance of BSA and glucose system incubated with ginger extract.

\subsection{Statistical Analysis}

The experimental results were carried out in triplicates $(n=3)$ and it was expressed by mean \pm Standard Error. Statistical analysis was performed using Data Entry: ANOVA test. $p$-values $<0.05$ were considered statistically significant.

\section{Conclusions}

In conclusion, this study revealed the in vitro antioxidant, anti-inflammatory and AGEs inhibiting property of ginger extract and suggested that the presence of flavonoids and related polyphenolic compounds may contribute to these activities. This study recommends the use of traditional medicines as an appreciated basis in potential search of natural product drugs and ginger extract may have beneficial effects in diabetes and glycation-induced complications. Our in vitro study suggests that a new generation of antidiabetic and anti-inflammatory drugs may be produced from ginger extract. For this purpose, further comprehensive chemical and pharmacological investigations are needed to find its precise mechanism against various health complications and active components behind such therapeutic activities, their cellular uptake, distribution as well as long-term effects and to confirm them.

Author Contributions: S.A. performed the experiments, analyzed/interpreted data and wrote the manuscript. A.A., K.S.A., R.J.J. and A.A.K. assisted in performing experiments and writing the manuscript. A.H.R. contributed 
to the concept, designed experiments, analyzed/interpreted data and finalized the manuscript. All authors have read and agreed to the published version of the manuscript.

Funding: The authors extend their appreciation to the Deputyship for Research \& Innovation, Ministry of Education in Saudi Arabia for funding this research work through the post-doc project program.

Conflicts of Interest: The authors declare no conflict of interest.

\section{References}

1. Safari, M.R.; Azizi, O.; Heidary, S.S.; Kheiripour, N.; Ravan, A.P. Antiglycation and antioxidant activity of four Iranian medical plant extracts. J. Pharmacopunct. 2018, 21, 82-89.

2. Younus, H.; Anwar, S. Antiglycating activity of Aloe vera gel extract and its active component aloin. J.P.P. 2018, 9, 115-125.

3. Younus, H.; Anwar, S. Prevention of non-enzymatic glycosylation (glycation): Implication in thetreatment of diabetic complication. Int. J. Health Sci. (Qassim) 2016, 10, 261-277. [CrossRef]

4. Khan, M.A.; Anwar, S.; Aljarbou, A.N.; Al-Orainy, M.; Aldebasi, Y.H.; Islam, S.; Younus, H. Protective effect of thymoquinone on glucose ormethylglyoxal-induced glycation of superoxidedismutase. Int. J. Biol. Macromol. 2014, 65, 16-20. [CrossRef]

5. Anwar, S.; Khan, M.A.; Sadaf, A.; Younus, H. A structural study on the protection of glycation of superoxide dismutase by thymoquinone. Int. J Biol Macromol. 2014, 69, 476-481. [CrossRef] [PubMed]

6. Anwar, S.; Younus, H. Antiglycating potential of ellagic acid against glucose and methylglyoxal-induced glycation of superoxide dismutase. J. Proteins Proteom. 2017, 8, 1-12.

7. Anwar, S.; Younus, H. Inhibitory effect of alliin from Allium sativum on the glycation of superoxidedismutase. Int. J. Biol. Macromol. 2017, 103, 182-193. [CrossRef]

8. Brownlee, M. The pathological implications of protein glycation. Clin. Invest. Med. 1995, 18, $275-281$.

9. Perez-Gutierrez, R.M. Inhibition of advanced glycation end products formation by stilbene and phenanthrene derivatives from Prosthechea michuacana in vitro and in vivo. Bol. Latinoam. Caribe. Plant Med. Aromat. 2013, 12, 69-80.

10. Kellow, N.J.; Coughlan, M.T. Effect of diet-derived advanced glycation end products on inflammation. Nutr. Rev. 2015, 73, 737-759. [CrossRef]

11. Huijberts, M.S.; Schaper, N.C.; Schalkwijk, C.G. Advanced glycation end products and diabetic foot disease. Diabetes Metab. Res. Rev. 2008, 24, S19-S24. [CrossRef] [PubMed]

12. Chicharro-Luna, E.; Pomares-Gomez, F.J.; Ortega-Avila, A.B.; Marchena-Rodriguez, A.; Blanquer-Gregori, J.F.J.; Navarro-Flores, E. Predictive model to identify the risk of losing protective sensibility of the foot in patients with diabetes mellitus. Int. Wound J. 2020, 17, 220-227. [CrossRef] [PubMed]

13. Kumar, D.; Ali, A. Antiglycation and antiaggregation potential of thymoquinone. Nat. Volatiles Essent. Oils 2019, 6, 25-33.

14. Fibach, E.; Rachmilewitz, E. The role of oxidative stress in hemolytic anemia. Curr. Mol. Med. 2008, 8, 609-619. [CrossRef] [PubMed]

15. Moskovitz, J.; Yim, M.B.; Chock, P.B. Free radicals and disease. Arch. Biochem. Biophys. 2002, 397, $354-359$. [CrossRef]

16. Marar, T. Amelioration of glucose induced hemolysis human erythrocytes by vitamin E. Chem. Biol. Interact. 2011, 193, 149-153. [CrossRef]

17. Yang, R.-L.; Shi, Y.-H.; Hao, G.; Li, W.; Le, G.-W. Increasing oxidative stress with progressive hyperlipidemia in human: Relation between malondialdehyde with atherogenic index. J. Clin. Biochem. Nutr. 2008, 43, 154-158. [CrossRef]

18. Sakat, S.S.; Juvekar, A.R.; Gambhire, M.N. In vitro antioxidant and anti-inflammatory activity of methanol extract of Oxalis corniculata linn. Int. J. Pharm. Pharm. Sci. 2010, 2, 146-155.

19. Xie, W.; Du, L. Diabetes is an inflammatory disease: Evidence from traditional Chinese medicines. Diabetes Obes. Metab. 2011, 13, 289-301. [CrossRef]

20. Ho, S.C.; Wu, S.P.; Lin, S.M.; Tang, Y.L. Comparison of anti-glycation capacities of several herbal infusions with that of green tea. Food Chem. 2010, 122, 768-774. [CrossRef] 
21. Maizura, M.; Aminah, A.; Wan Aida, W.M. Total phenolic content and antioxidant activity of kesum (Polygonum minus), ginger (Zingiber officinale) and turmeric (Curcuma longa) extract. Int. Food Res. J. 2011, 18, 529-534.

22. Wu, C.-H.; Huang, S.-M.; Yen, G.-C. Silymarin: A novel antioxidant with antiglycation and antiinflammatory properties in vitro and in vivo. Antioxid. Redox Sign. 2011, 14, 353-366. [CrossRef] [PubMed]

23. Ramkissoon, J.S.; Mahomoodally, M.F.; Ahmed, N.; Subratty, A.H. Antioxidant and anti-glycation activities correlates with phenolic composition of tropical medicinal herbs. Asian Pac. J. Trop. Med. 2013, 6, 561-569. [CrossRef]

24. Nag, A.; Bandyopadhyay, M.; Mukherjee, A. Antioxidant activities and cytotoxicity of Zingiber zerumbet (L.) smith rhizome. J. Pharmacogn. Phytochem. 2013, 2, 102-108.

25. Jafarzadeh, A.; Nemati, M. Therapeutic potentials of ginger for treatment of Multiple sclerosis: A review with emphasis on its immunomodulatory, anti-inflammatory and anti-oxidative properties. J. Neuroimmunol. 2018, 324, 54-75. [CrossRef]

26. Ali, B.H.; Blunden, G.; Tanira, M.O.; Nemmar, A. Some phytochemical, pharmacological and toxicological properties of ginger (Zingiber officinale Roscoe): A review of recent research. Food Chem. Toxicol. 2008, 46, 409-420. [CrossRef]

27. Langner, E.; Greifenberg, S.; Gruenwald, J. Ginger: History and use. Adv. Ther. 1998, 15, $25-44$.

28. Dias, M.I.; Sousa, M.J.; Alves, R.C.; Ferreira, I.C.F.R. Exploring plant tissue culture to improve the production of phenolic compounds: A review. Ind. Crop Prod. 2016, 82, 9-12. [CrossRef]

29. Ajandouz, E.H.; Tchiakpe, L.S.; Ore, F.D.; Benajiba, A.; Puigserver, A. Effect of pH on caramelization and Maillard reaction kinetics in fructose-lysine model systems. J. Food Sci. 2011, 66, 926-931. [CrossRef]

30. Aruoma, O.I.; Halliwell, B.; Dizdaroglu, M. Iron ion-dependent modification of bases in DNA by the superoxide radical-generating system hypoxanthine/xanthine oxidase. J. Biol. Chem. 1989, 264, 13024-13028.

31. Navarro-Flores, E.; Cauli, O. Quality of life in individuals with diabetic foot syndrome. Endocrine Metab. Immune Disord. Drug Targets 2020, 20, 1-8. [CrossRef] [PubMed]

32. Navarro-Flores, E.; Perez-Ros, P.; FM, M.-A.; Julian-Rochina, I.; Cauli, O. Neuro-psychiatric alterations in patients with diabetic foot syndrome. CNS Neurol. Disord. Drug Targets 2019, 18, 598-608. [CrossRef] [PubMed]

33. Banan, P.; Ali, A. Preventive effect of phenolic acids on in vitro glycation. Ann. Phytomed. 2016, 5, 97-102. [CrossRef]

34. Miroliaei, M.; Aminjafari, A.; Ślusarczyk, S.; Nawrot-Hadzik, I.; Rahimmalek, M.; Matkowski, A. Inhibition of glycation-induced cytotoxicity, protein glycation, and activity of proteolytic enzymes by extract from Perovskia atriplicifolia roots. Pharmacogn. Mag. 2017, 13, S676-S683. [PubMed]

35. Salahuddin, P.; Rabbani, G.; Khan, R.Z. The role of advanced glycation end products in various types of neurodegenerative disease: A therapeutic approach. Cell Mol. Biol. Lett. 2014, 19, 407-437. [CrossRef]

36. Scanlon, V.C.; Sanders, T. Essentials of Anatomy and Physiology, 6th ed.; F.A. Davis Company: Philadelphia, PA, USA, 2010; p. 287.

37. Brown, J.H.; Mackey, H.K. Inhibition of heat-induced denaturation of serum proteins by mixtures of non-steroidal anti-inflammatory agents and amino acids. Proc. Soc. Exp. Biol. Med. 1968, 128, 225-228. [CrossRef]

38. Ordonez, A.; Gomez, J.; Vattuone, M. Antioxidant activities of Sechium edule (Jacq.) Swartz extracts. Food Chem. 2006, 97, 452-458. [CrossRef]

39. Taie, H.A.A.; Salama, Z.A.-E.R.; Radwan, S. Potential activity of basil plants as a source of antioxidants and anticancer agents as affected by organic and bio-organic fertilization. Not. Bot. Horti. Agrobo. 2010, 38, 119-127.

40. Aljohi, A.; Matou-Nasri, S.; Ahmad, N. Antiglycation and antioxidant properties of Momordica charantia. PLoS ONE 2016, 11, e0159985. [CrossRef] [PubMed]

41. Ruch, R.J.; Cheng, S.J.; Klaunig, J.E. Prevention of cytotoxicity and inhibition of intercellular communication by antioxidant catechins isolated from Chinese green tea. Carcinogenesis 1089, 10, 1003-1008. [CrossRef]

42. Mizushima, Y.; Kobayashi, M. Interaction of anti-inflammatory drugs with serum preoteins, especially with some biologically active proteins. J. Pharma. Pharmacol. 1968, 20, 169-173. [CrossRef] [PubMed]

43. Oyedepo, O.O.; Femurewa, A.J. Anti-protease and membrane stabilizing activities of extracts of Fagra zanthoxiloides, Olax subscorpioides and Tetrapleura tetraptera. Int. J. Pharmacong. 1995, 33, 65-69. [CrossRef] 
44. Chanda, S.; Juvekar, A. In vitro anti-inflammatory activity of syringic acid. Int. J. Pharm. Pharm. Sci. 2019, 11, 71-73. [CrossRef]

45. Rodrigues, C.F.; Rodrigues, M.E.; Henriques, M. Candida sp. infections in patients with diabetes mellitus. J. Clin. Med. 2019, 8, 76. [CrossRef]

46. Hamad, H.O.; Alma, M.H.; Ismael, H.M.; Goceri, A. The effect of some sugars on the growth of Aspergillus niger. KSU J. Nat. Sci. 2014, 17, 7-11. [CrossRef]

47. Henderson, E.K.M. Isolation, identification and growth of some soil hyphomycetes and yeast-like fungi which utilize aromatic compounds related to lignin. J. Gen. Microbial. 1961, 26, 149-154. [CrossRef]

48. Brownlee, M.; Vlassara, H.; Kooney, A.; Ulrich, P.; Cerami, A. Aminoguanidine prevents diabetes induced arterial wall protein cross-linking. Science 1986, 232, 1629-1632. [CrossRef]

49. Klunk, W.E.; Jacob, R.F.; Mason, R.P. Quantifying amyloid beta-peptide (Abeta) aggregation using the Congo red-Abeta (CR-abeta) spectrophotometric assay. Anal. Biochem. 1999, 266, 66-76. [CrossRef]

(C) 2020 by the authors. Licensee MDPI, Basel, Switzerland. This article is an open access article distributed under the terms and conditions of the Creative Commons Attribution (CC BY) license (http://creativecommons.org/licenses/by/4.0/). 